\section{Reduction of MTT by Glutathione S-Transferase}

BioTechniques 25:622-628 (October 1998)

\begin{abstract}
The reduction of the tetrazolium salt 3-(4,5-dimethylthiazol-2-yl)-2,5-diphenyl tetrazolium bromide (MTT) to a blue formazan product is widely used for assaying cell survival and proliferation. The reduction reaction is catalyzed by dehydrogenases localized in the mitochondria of viable cells. As part of an analysis of the ability of glutathione S-transferase (GST) enzymes to protect cells from electrophilic compounds, we found extremely high background levels of the formazan product produced by cells that overexpressed the mouse GST P1-1 enzyme. Further analysis with purified GST enzymes confirmed the ability of these enzymes to reduce MTT in vitro. These data suggest that cytotoxicity assays using MTT should be interpreted with caution, especially when studying the effects of compounds that can influence GST expression.
\end{abstract}

\section{INTRODUCTION}

The reduction of tetrazolium salts to formazans in living cells has long been used to assess cell proliferation and to measure reductase enzymes $(1,4,5,10$, 16). For cell growth and survival assays, the tetrazolium salt 3-(4,5-dimethylthiazol-2-yl)-2,5-diphenyl tetrazolium bromide (MTT) is currently widely used because of its convenience and suitability for automation using microplate readers (4). MTT is also widely used in cytotoxicity assays as a means to assess the ability of cloned enzymes to protect cells from various toxins or pro-toxins, and several model systems have been developed. These include stably or transiently transfected mammalian cells $(13,22)$, vaccinia virus expression systems (7) and baculovirus expression systems (9). During the course of a study designed to assess the ability of baculovirus-expressed glutathione S-transferase (GST) enzymes to protect $S f 21$ cells from electrophilic xenobiotics, we found that cells expressing GSTs had considerable higher rates of MTT reduction compared with control cells. In this report, we show that mouse (m)GST isozymes catalyze the glutathione-dependent reduction of MTT at a low, but potentially significant, rate. These results suggest that MTT might not be a suitable indicator of cell viability in cells expressing high levels of GSTs or in cells treated with compounds that alter GST expression levels.

\section{MATERIALS AND METHODS}

\section{Materials}

Glutathione-Sepharose ${ }^{\circledR}$ glutathione (GSH), Pen/Strep antibiotics, MTT and 1-chloro-2,4-dinitrobenzene (CDNB) were purchased from Sigma Chemical (St. Louis, MO, USA). Protein assay reagents based on the Bradford (3) dyebinding procedure were obtained from Bio-Rad (Hercules, CA, USA). EXCELL $^{\mathrm{TM}} 401$ medium was purchased from JRH Biosciences (Lenexa, KS, USA); fetal calf serum (FCS) was purchased from Intergen (Purchase, NY, USA).

\section{Preparation of Overexpressed GSTs}

Construction of recombinant baculoviruses. The full-length cDNAs for the mGST P1-1 $(\pi)$, mGST A3-3 (Yc) or mGST A4-4 were separately cloned into the p2Bac ${ }^{\mathrm{TM}}$ Transfer Vector (Invitrogen, Carlsbad, CA, USA) downstream of the polyhedrin promoter. Recombinant transfer plasmid was then co-transfected with Bsu36I-cut BacPAK6 Viral DNA (CLONTECH Laboratories, Palo Alto, CA, USA) using CELLFECTIN ${ }^{\mathrm{TM}}$ Reagent (Life Technologies, Gaithersburg, MD, USA) as previously described (17). Following four cycles of plaque purification, recombinant viruses were amplified and analyzed for GST expression by sodium dodecyl sulfate polyacrylamide gel electrophoresis (SDS-PAGE). The control virus used throughout these experiments was the nonrecombinant BacPAK6 virus expressing $\beta$-galactosidase ( $\beta$-gal).

$S f 21$ cell infection. $S f 21$ cells were maintained and passaged in complete media containing $3 \%$ heat-inactivated
FCS and $1 \%$ Pen/Strep antibiotics. Sf 21 cells $\left(5 \times 10^{7}\right.$ cells $)$ were placed in a 50-mL conical tube and infected with 5 $\times 10^{6}$ recombinant viruses. Infected cells were gently rocked for $1 \mathrm{~h}$ and then transferred to spinner flasks. Complete medium was added to bring the cell concentration to $1 \times 10^{6}$ cells $/ \mathrm{mL}$. Spinner flasks were incubated at $27^{\circ} \mathrm{C}$, with stir bars rotating at $60 \mathrm{rpm}$.

Addition of glutathione. On day 2 post-infection, BacPAK6- and GST- $\pi$ infected $S f 21$ cells were each divided in half and placed in separate spinner flasks. One flask of each virus culture received GSH (5 mM final concentration) diluted in media. The second flask of each culture received an equivalent volume of media. The MTT metabolism and cell-density assays were performed on all four cultures for the remainder of the time course.

Cell density. A representative sample was removed from each flask daily. The samples were diluted in phosphatebuffered saline (PBS), and the number of cells per milliliter in each sample was determined using a hemacytometer.

MTT assay. Samples $(0.5 \mathrm{~mL})$ from each culture were incubated with MTT $(1 \mu \mathrm{g} / \mu \mathrm{L})$, for $1 \mathrm{~h}$ at $27^{\circ} \mathrm{C}$ in 24 -well polystyrene plates. Cells were then lysed in the dark overnight at room temperature in lysing buffer (9). The solubilized MTT hydrolysis product was quantified by measuring the optical density (OD) at $570 \mathrm{~nm}$ using a SPECTRAmax $^{\circledR} 250$ Microplate Reader (Molecular Devices, Sunnyvale, CA, USA). All values were subtracted against a media blank.

CDNB assay. GST-specific activity was determined for each virus culture daily by measuring the rate of GSH conjugation to CDNB. Cells were collected and washed 2 times in PBS, 5 mM EDTA, then lysed by freeze/thawing. For the assay, samples were diluted in substrate buffer $\left(100 \mathrm{mM} \mathrm{KH}{ }_{2} \mathrm{PO}_{4}\right.$, $15 \%$ glycerol, pH 6.8), GSH (5 mM, final concentration) and CDNB (0.28 $\mathrm{mM}$, final concentration) were added to the wells to start the reaction. The rate of GSH conjugation to CDNB was measured at $340 \mathrm{~nm}$ for $5 \mathrm{~min}$, at $11-\mathrm{s}$ intervals using the SPECTRAmax microplate reader. The rate of product formation was calculated using the first 5 points collected. The specific activity 

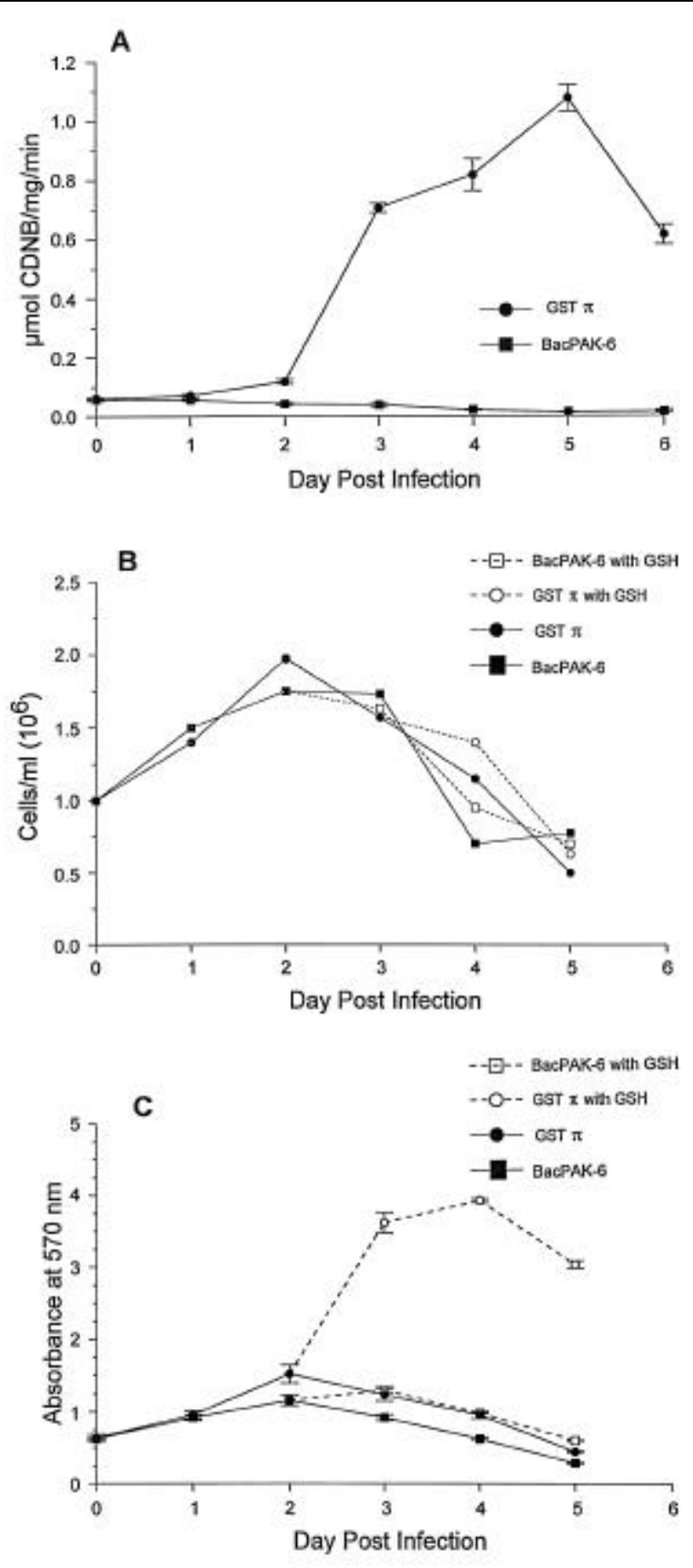

Figure 1. Characterization of GST activity in BacPAK6- and GST- $\boldsymbol{\pi}$-infected $\boldsymbol{S} \boldsymbol{2 1}$ cells. (A) GSTspecific activity was measured as the rate of GSH conjugation to CDNB. The BacPAK6-infected cells showed low levels of GST activity, in contrast, GST- $\pi$ expressing $S f 21$ cells showed high levels of expression at 3-5 days post-infection. (B) Determination of cell density in virus-infected cultures. Cells were counted daily using a hemacytometer. For both BacPAK6- and GST- $\pi$-infected cultures, cell density peaked at day 2 . The addition of $5 \mathrm{mM} \mathrm{GSH}$ caused no apparent changes in cell density for either virus-infected culture. (C) MTT metabolism in virus-infected cultures. MTT metabolism in the BacPAK6-infected cells peaked at day 2 post-infection. The addition of GSH to the BacPAK6 culture caused a small increase in MTT metabolism. In the GST- $\pi$-infected culture without exogenous GSH, peak MTT metabolism occurred on day 2 post-infection. The addition of $5 \mathrm{mM}$ GSH caused an apparent 3-fold-4fold increase in the amount of MTT formazan product in the GST- $\pi$ cultures. The high levels of MTT metabolism paralleled the rise in GST activity observed in the GST- $\pi$ infected cultures. was calculated using an extinction coefficient of $10.09(\mathrm{OD} \times \mathrm{L}) / \mathrm{mmol}(8)$.

Glutathione assay. Cells were washed in $1 \times$ PBS and deproteinized by incubation with an equal volume of $5 \%$ sulfosalicylic acid. The resulting supernatants were used to measure GSH as previously described (21). Results are expressed as picomole GSH/ microgram protein using day-3, postinfection samples.

\section{Purification of Overexpressed GSTs}

At 4 days post-infection, cells were centrifuged at $325 \times g$ for $15 \mathrm{~min}$, washed with PBS and homogenized with a Potter-Elvehjem Homogenizer (Kontes, Vineland, NJ, USA). The supernatants were prepared by centrifuging the homogenate at $60000 \times g$ for 1 h. GST in the supernatant was affinitypurified on a $0.9-\times 4-\mathrm{cm}$ GlutathioneSepharose ${ }^{\circledR}$ column as previously described (2).

\section{Rate of Formazan Formation Using Affinity-Purified GSTs}

MTT (5 mM) and GSH (2 mM, final concentrations) were incubated at $37^{\circ} \mathrm{C}$ in $50 \mathrm{mM}$ sodium phosphate buffer, $\mathrm{pH}$ 6.25 , along with $6 \mu \mathrm{g}$ of affinity-purified GST in a total volume of $200 \mu \mathrm{L}$ for various times. The $\mathrm{pH}$ was chosen so that there was appreciable enzymatic activity with no uncatalyzed reduction of MTT by GSH. At a given time, the reaction was stopped by the addition of $0.6 \mathrm{~mL}$ of stopping solution, which consisted of $10 \%$ SDS and $45 \%$ dimethyl formamide (DMF), adjusted to $\mathrm{pH} 4.5$ with glacial acetic acid. The absorbance was read at $592 \mathrm{~nm}$ in a Model 124 Double-Beam Spectrometer (Hitachi Scientific Instruments, Mountain View, CA, USA) after $2 \mathrm{~h}$ of additional incubation, which was necessary to completely dissolve the precipitated formazan. Based on an extinction coefficient of 17.4 at $505 \mathrm{~nm}$ (1) in DMF, we determined an extinction coefficient of 19.8 at $592 \mathrm{~nm}$ in the stopping solution for the reduced MTT. MTT was chemically reduced with a 3 -fold excess of GSH in $50 \mathrm{mM}$ Tris-base, $\mathrm{pH}$ 9.0 for $18 \mathrm{~h}$ in the dark under nitrogen. The colored precipates were washed with water and redissolved in DMF. 


\section{Short Technical Reports}

\section{RESULTS}

Figure 1 shows the pattern of BVGST- $\pi$ and BacPAK6 expression in Sf 21 cells during the infection cycle. GST activity was measured as CDNBspecific activity (Figure 1A). BV-GST$\pi$-infected cells showed expression of GST beginning at day 3 post-infection; highest levels were found at day 5 postinfection. The control virus BacPAK6, which expresses $\beta$-gal, did not show appreciable levels of GST activity during any part of the virus-infection cycle. The addition of GSH at day 2 postinfection did not change cell density in either the BV-GST- $\pi$ - or BacPAK6-infected cultures (Figure 1B). The level of MTT reduction in the BV-GST- $\pi$-infected cells without exogenous GSH was similar to the level of MTT reduction in the control $\beta$-gal-expressing cells with or without exogenous GSH. However, the GST-expressing Sf 21 cells showed high levels of MTT reduction when exogenous GSH was added (Figure 1C). These results suggested the possibility that GST protein [released from $S f 21$ cells because of virus infection (17)] was catalyzing the reduction of MTT.

To address this question, studies were performed to determine whether purified GST- $\pi$ and other GST isozymes were capable of reducing MTT to its formazan product. Figure 2 shows the rate of reduced MTT formation catalyzed by equal amounts of three different affinity-purified GST isozymes under conditions described in Materials and Methods. In the absence of GST or $\mathrm{GSH}$, there is no reduction of MTT.

The Michaelis-Menten constant $\left(K_{\mathrm{m}}\right)$ was determined for GSH using a nominal value of $5 \mathrm{mM}$ for MTT. Under these conditions, the $K_{\mathrm{m}}$ for GSH was found to be $2 \mathrm{mM}$ and was not statistically different between the GST isozymes. The $K_{\mathrm{m}}$ for MTT was then determined for the $\pi$ and mGST A4-4 isozymes at saturating GSH levels (5 $\mathrm{mM})$. The data were fit to the Michaelis-Menten equation using SigmaPlot $^{\circledR}$ Version 5.0 software with iterative nonlinear curve fitting (SPSS, Chicago, IL, USA). Table 1 shows the best fit values for $K_{\mathrm{m}}$ and maximum velocity $\left(\mathrm{V}_{\max }\right)$. To establish that the product of the GST-catalyzed reaction

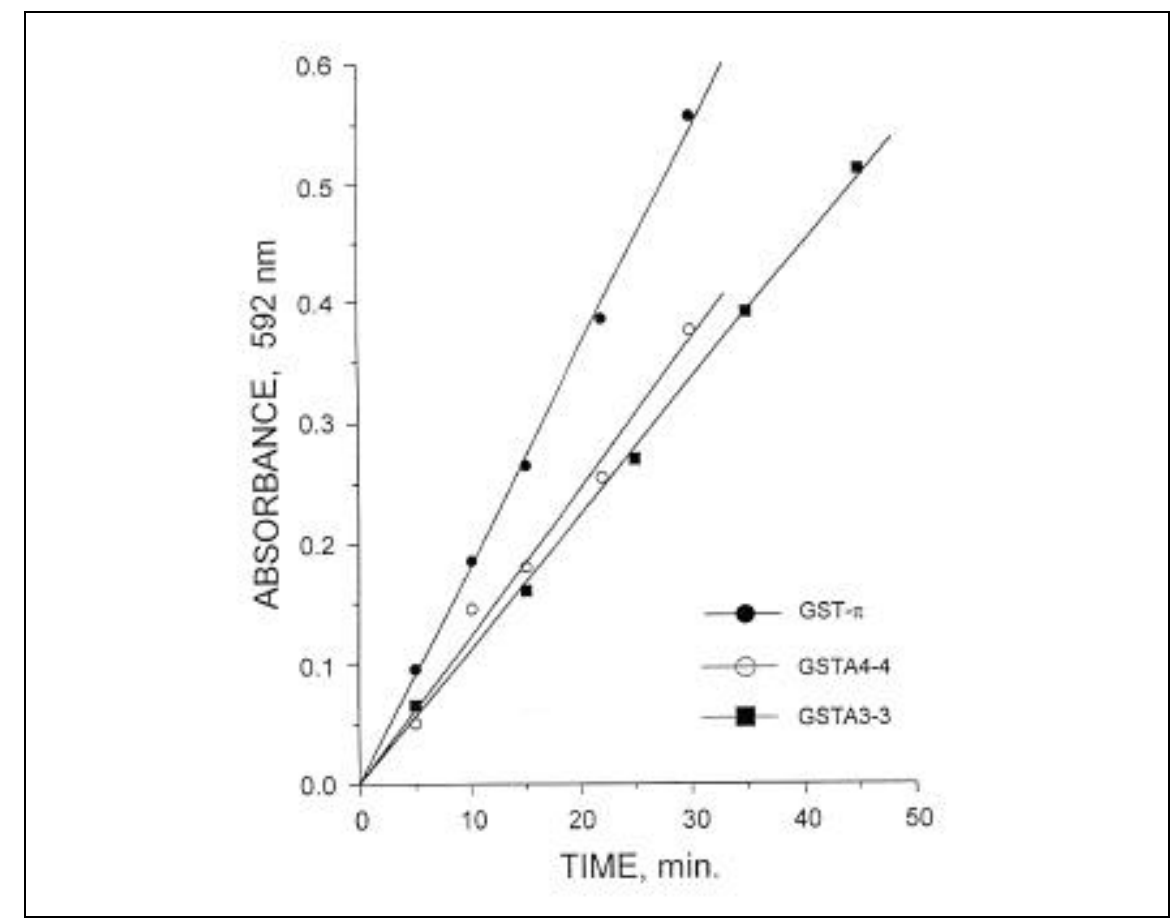

Figure 2. Kinetics of the GST catalyzed reduction of MTT. MTT ( $5 \mathrm{mM})$ and GSH (2 mM) were incubated at $37^{\circ} \mathrm{C}$ in $50 \mathrm{mM}$ sodium phosphate buffer, $\mathrm{pH} 6.25$, with $6 \mu \mathrm{g}$ of each purified GST isozyme in a total volume of $200 \mu \mathrm{L}$ for the indicated times. The reactions were terminated by the addition of 0.6 $\mathrm{mL}$ of a SDS/DMF stopping solution. The amount of reduced MTT formed was measured at $592 \mathrm{~nm}$.

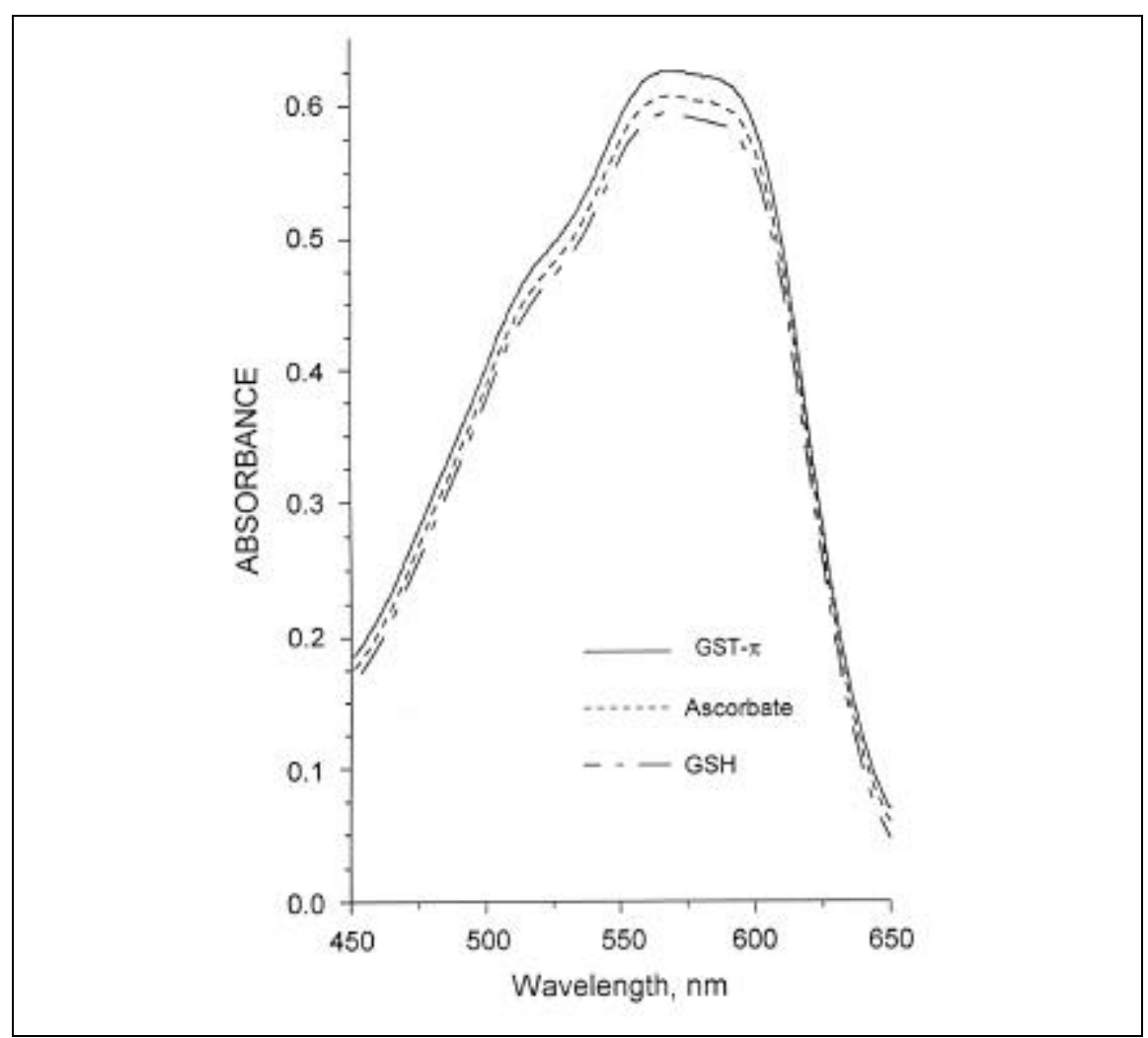

Figure 3. Absorbtion spectra following the reduction of MTT by mGST- $\pi$, ascorbate or GSH as described in Materials and Methods. The spectra were offset from each other by 0.01 absorbance units for clarity of presentation. 
between MTT and GSH was the same as that generated by ascorbate reduction (1) or by reduction with GSH alone, the spectra of the formazans prepared under these conditions were compared at the same concentrations in SDS/DMF stopping solution (Figure 3 ). The results showed that all three spectra were essentially identical.
Table 1. Kinetic Parameters for GST Isozymes Using MTT

\begin{tabular}{|lcc|}
\hline GST Isozyme & $\boldsymbol{K}_{\mathbf{m}}(\mathbf{m M}) \pm$ SEMa & $\mathbf{V}_{\mathbf{m a x}}(\mathbf{n m o l} / \mathbf{m i n} / \mathbf{m g}) \pm$ SEM $^{\mathbf{a}}$ \\
\hline$\pi$ & $5.49 \pm 0.95$ & $164.9 \pm 15.7$ \\
A4-4 & $6.41 \pm 1.63$ & $98.0 \pm 14.7$ \\
aSEM = standard error of the mean. & \\
\hline
\end{tabular}

\section{DISCUSSION}

These studies demonstrate that GSTs are capable of reducing MTT, and that this reaction can occur to an appreciable extent. The elevated level of MTT metabolism was not due to increased cell number within the cultures, and it only occurred when GST and exogenous GSH were present. The endogeneous level of GSH in various cell types ranges from $0.5-8 \mathrm{mM}(18)$. We found a GSH concentration of 21 $\mathrm{pmol} / \mu \mathrm{g}$ protein [standard deviation $(\mathrm{SD})= \pm 12.0]$ for the GST- $\pi$-infected $S f 21$ cells at 3 days post-infection (data not shown). Based on protein assays, Sf 21 cells have approximately $0.2 \mathrm{ng}$ of protein per cell (data not shown). Because $S f 21$ cells are essentially spherical and have a radius of approximately $0.01 \mathrm{~mm}$, we calculate that the intracellular GSH concentration would be approximately $0.5 \mathrm{mM}$. This is one-fourth lower than the $K_{\mathrm{m}}$ of the GSTs for GSH and would explain the low level of MTT reduction without exogenously added GSH.

The studies using purified enzymes confirm that GSTs are capable of reducing MTT to its formazan product. These results could have important implications when measuring viability in cells with high levels of GST activity and with relatively high levels of intracellular GSH.

In our studies with purified GST, the $K_{\mathrm{m}}$ values for mGST- $\pi$ and mGST A44 are very similar, both for GSH and MTT. Therefore, the differences between the two isozymes in the observed rate with MTT (Figure 2) can be attributed to differences in the catalytic step. Mechanistically, we propose that GST isozymes are catalyzing the reduction of MTT by GSH, a typical peroxidase activity, rather than catalyzing a covalent addition of GSH to MTT; the 
absorption spectrum (Figure 3 ) of the solubilized formazan product of this reaction is identical to that observed for the product produced by the chemical reduction of MTT (1). Although UV spectra are not proof of structural identity, if covalent addition of GSH to the tetrazole ring system of MTT were occurring, one would expect such addition would break the conjugated $\pi$ electron system, resulting in a shift in the UV spectrum of the MTT-GSH adduct to the blue. This does not occur. Also, the product produced by the GST-catalyzed reaction is not soluble in aqueous solution as would be expected for a GSH adduct of MTT.

Although mGST A4-4 (15) and GST A3-3 (14) are $\alpha$-class isozymes with significantly greater peroxidase activity than GST- $\pi$-class isoenzymes (as measured with cumene hydroperoxide) (14), in this study with MTT as substrate, there is greater peroxidase activity with the $\pi$ enzyme (Figure 2).

GST isozymes, especially GST- $\pi$ isozymes, are known to be overexpressed in a variety of tumor cells used for studying resistance to chemotherapeutic drugs (20). In these cells, GSTs can play a significant role in MTT reduction compared to mitochondrial enzymes. In addition, GSTs are a readily inducible group of enzymes, responding to a wide range of xenobiotic inducers $(6,11,12,19)$. Our results suggest that endogenous GST levels and GST induction should be considered when interpreting the results of MTT assays as a measure of cell viability.

\section{REFERENCES}

1.Altman, F.P. 1976. Tetrazolium salts and formazans. Prog. Histochem. Cytochem. 9:1-56.

2.Benson, A.M., M.J. Hunkeler and J.L. York. 1989. Mouse hepatic glutathione transferase isoenzymes and their differential induction by anticarcinogens. Specificities of butylated hydroxyanisole and bisethylxanthogen as inducers of glutathione transferases in male and female CD-1 mice. Biochem. J. 261:1023-1029.

3.Bradford, M.M. 1976. A rapid and sensitive method for the quantitation of microgram quantities of protein utilizing the principle of protein-dye binding. Anal. Biochem. 72:248254.

4.Carmichael, J., W.G. DeGraff, A.F. Gazdar, J.D. Minna and J.B. Mitchell. 1987. Evaluation of a tetrazolium-based semiautomated colorimetric assay: assessment of chemosensitivity testing. Cancer Res. 47:936-942.

5.Denizot, F. and R. Lang. 1986. Rapid colorimetric assay for cell growth and survival. Modifications to the tetrazolium dye procedure giving improved sensitivity and reliability. J. Immunol. Methods 89:271-277.

6.Flomerfelt, F.A., M.M. Briehl, D.R. Dowd, E.S. Dieken and R.L. Miesfeld. 1993. Elevated glutathione S-transferase gene expression is an early event during steroid-induced lymphocyte apoptosis. J. Cell Physiol. 154:573-581.

7.Gonzalez, F.J., T. Aoyama and H.V. Gelboin. 1991. Expression of mammalian cytochrome $\mathrm{P} 450$ using vaccinia virus. Methods Enzymol. 206:85-92.

8.Grant, D.F., D.M. Bender and B.D. Hammock. 1989. Quantitive kinetic assays for glutathione S-transferase and general esterase in individual mosquitoes using an EIA reader. Insect Biochem. 19:741-751.

9.Grant, D.F., J.F. Greene, F. Pinot, B. Borhan, M.F. Moghaddam, B.D. Hammock, B.F. McCutchen, H. Ohkawa, G. Luo and T.M. Guenthner. 1996. Development of an in situ toxicity assay system using recombinant baculoviruses. Biochem. Pharmacol. 51:503-515.

10.Hansen, M.B., S.E. Nielsen and K. Berg. 1989. Re-examination and further development of a precise and rapid dye method for measuring cell growth/cell kill. J. Immunol. Methods 119:203-210.

11.Hincal, F., A. Gurbay and B. Giray. 1995. Induction of lipid peroxidation and alteration of glutathione redox status by endosulfan. Biol. Trace Elem. Res. 47:321-326.

12.Katoh, T., H. Ohmori, T. Murakami, Y. Karasaki, K. Higashi and M. Muramatsu. 1991. Induction of glutathione-S-transferase and heat-shock proteins in rat liver after ethylene oxide exposure. Biochem. Pharmacol. 42:1247-1254.

13.Langenbach, R., P.B. Smith and C. Crespi. 1992. Recombinant DNA approaches for the development of metabolic systems used in in vitro toxicology. Mutat. Res. 277:251-275.

14.Mannervik, B. and U.H. Danielson. 1988. Glutathione transferases-structure and catalytic activity. CRC Crit. Rev. Biochem. 23:283-337.

15.Medh, R.D., M. Saxena, S.S. Singhal, H. Ahmad and Y.C. Awasthi. 1991. Characterization of a novel glutathione S-transferase isoenzyme from mouse lung and liver having structural similarity to rat glutathione S-transferase 8-8. Biochem. J. 278:793-799.

16.Mosmann, T. 1983. Rapid colorimetric assay for cellular growth and survival: application to proliferation and cytotoxicity assays. J. Immunol. Methods 65:55-63.

17.O'Reilly, D.R., L.K. Miller and V.A. Luckow. 1992. Baculovirus Expression Vectors: A Laboratory Manual. Freeman and Company, New York.

18.Richie, J.P., Jr. 1992. The role of glutathione in aging and cancer. Exp. Gerontol. 27:615626.

19.Telakowski-Hopkins, C.A., R.G. King and C.B. Pickett. 1988. Glutathione S-transferase Ya subunit gene: identification of regulatory elements required for basal level and inducible expression. Proc. Natl. Acad. Sci. USA 85:1000-1004.

20.Tew, K.D. 1994. Glutathione-associated enzymes in anticancer drug resistance. Cancer Res. 54:4313-4320.

21. Tietze, F. 1969. Enzymic method for quantitative determination of nanogram amounts of total and oxidized glutathione: applications to mammalian blood and other tissues. Anal. Biochem. 27:502-522.

22.Zimniak, L., S. Awasthi, S.K. Srivastava and P. Zimniak. 1997. Increased resistance to oxidative stress in transfected cultured cells overexpressing glutathione S-transferase mGSTA4-4. Toxicol. Appl. Pharmacol. 143:221-229.

The mouse GST- $\pi$ and GST A3-3 were generously provided by David Eaton, University of Washington, Seattle. We thank Christine Halmes for technical help and Dr. Donald C. DeLuca, University of Arkansas for Medical Sciences, for the spectra of the MTT formazans. This work was supported in part by a National Institutes of Health Grant No. R01 GM 56708. Address correspondence to Dr. David F. Grant, Department of Pharmacology and Toxicology, University of Arkansas for Medical Sciences, Slot 638, 4301 W. Markham, Little Rock, AR 72205, USA. Internet: grantdavidf @exchange.uams.edu

Received 5 May 1998; accepted 24 June 1998.

\section{J.L. York, L.C. Maddox, P. Zimniak, T.E. McHugh ${ }^{1}$ and D.F. Grant University of Arkansas for Medical Sciences and John McClellan VA Memorial Hospital Little Rock, AR ${ }^{1}$ Groundwater Services, Inc. Houston, TX, USA}

